\title{
Regionalization of Non-State Security Agencies in Southwest Nigeria: Prospects and Challenges of "Amotekun"
}

\author{
Odewale Ayotunde David, PhD \\ Lamidi Kazeem Oyedele, PhD \\ Department of Local Government and Development Studies, \\ Obafemi Awolowo University Ile-Ife, Osun State, Nigeria
}

Doi:10.19044/esj.2020.v16n20p103 URL:http://dx.doi.org/10.19044/esj.2020.v16n20p103

\begin{abstract}
The necessity of policing by all actors, both the state and non-state, becomes more expedient in Nigeria societies characterized by diver's insecurities vices range from book-haram insurgency, kidnapping, banditry, armed robbery, herdsmen/ farmer clash, and ritual killing. The process of localizing security architecture is essential in Nigeria federation, so as tackled this menace of insecurities that have been threating the unity of Nigeria nation. This paper examines the modalities and theoretical insights of the operation Amotekun initiative in the Southwest Nigeria with a view to providing information on the prospects and challenges of the regional security network. Data was garnered basically from secondary sources. It is assumed that the criminality that have pervaded the southwest Nigeria could be reduce to minimal, if the initiative is well managed, and in extension, to the entire federation. The paper identified some challenges that may confront the initiative, which range from; unnecessary suspicion among the nations in Nigeria federation, conflict with other statutory security agencies, and using the initiative to settle personal discord among others. It recommends the need for legal framework from each states of the region for its establishment, operations and finance and appropriate synergy among all the tiers of government and agencies of government in security sector so as to achieve the ultimate goal of securing lives and properties. The paper concluded that operation Amotekun should be nurtured because there is nothing too big in securing the lives and properties of the citizen, which is the primary function of any government.
\end{abstract}

Keywords: Regionalization, Policing, Non- State, Security, Insecurity, Southwest, Nigeria 


\section{Introduction}

Security of lives and properties is though exclusive function of government which permeates all strata of society (Iloh \& Nwokedi, 2019). Prior to government formation, the quest for security in kingdoms and empires are evident in the traditional administrative settings. In Nigeria, communities tend to demonstrate security architecture with upspring from local chiefs. For instance, the great warriors, i.e Balogun and the formations are good examples in Yorubaland. Also, there are strata of the security guards among the agegrades in Igboland. However, the centralized administrative system in Hausaland provided a more formidable security structure through the Galadima. This concretized the influx of non-state network on the internal security arrangement in Nigeria. In support of these local security network, Prof. Itse Sagay (SAN) the Chairman, Presidential Advisory Committee against Corruption (PACAC) believed that it is not too good for the whole nation to depend completely on the federal government for security, but should rely more and more on local initiative, so that who feel the pain are those who try to take control of the security situation. Furthermore, Ikuteyijo (2008) observed that the inability of the police to stem to surging crime waves by enforcing the security of lives and properties has compelled the community members to turn from the formal way of enforcing a law to various self-help initiatives to secure themselves.

In recent times, the recurring decimal of social crimes, like banditry, kidnapping among other violent acts, necessitated the reinvigoration of the informal approaches to the security of lives and properties. At first, group formations were noticeable as an informal response to criminal threats, such as burglary, pot-theft, and home-breaking cases. More intensity of these crimes also informed the street policing, as a concept, which has not really enjoyed discourse but evidence based. Moreover, its re-occurrence in different dimensions and forms ignited the current debate on community policing across states in Nigeria with some quick formation, such as Hisbah police amongst of joint task forces in the country. More especially, the police-community relation committee is a standing unit for interactions and operations of communal security issues.

Specifically in Southwest Nigeria, most notable across communities is the outfit of vigilante groups and factions of Oodua Peoples' Congress (OPC). In spite of these outfits, high prevalence of kidnapping along highways, farmland invasion by herdsmen, bank robbery in Southwest Nigeria called for regional impulse of the security outfit christened Western Nigeria Security Network (WNSN) with a code-name of Amotekun. The "Amotekun" means leopard in the Yoruba language, and is an operational nomenclature for the (WNSN) which was launched on Thursday9 ${ }^{\text {th }}$ January 2020. The leopard symbolizes strength, perseverance, ambition, independence, toughness, 
patience, wisdom and fearlessness. Amotekun is also known for its unique hunting behavior and a well-camouflaged fur which enables to defend its territories from intruders. WNSN is a regional security outfit to battle criminality in the region which consists of Lagos, Ogun, Oyo, Osun, Ondo, and Ekiti states. The outfit would consist of the vigilante group each of the states of the region, security experts and other Yoruba socio-cultural groups engage in local security, such as Oodua Peoples Congress (OPC) and "Agbekoya" to complement the activities of conventional policing such as Nigeria Police Force (NPF), NSCDC, among other state security establishments.

The launching of the initiative has enjoyed different opinions; some commend the initiative while some also against it. The criticism of the initiative especially from the Northern extraction, Northern Youth Council of Nigeria (NYCN) express fear and described the initiative as Oodua Peoples Congress (OPC) military wing in disguise. The Attorney General of the Federation (AGF) and the Minister of Justice, Abubakar Malami declared the outfit as the illegal base on the constitutional split of the exclusive legislation of police as the only recognized agency to provide security of lives and properties. Meanwhile, many Nigerians, among whom Chief Afe Babalola (SAN) and Femi Falana (SAN) had also condemned the statement accredited to the AGF as ultra-vires that is the AGF lacks the locus standing to declare the outfit illegal expect the competent court of jurisdiction. Some also believed that the Southwest region is trying to create the State Police since the federal government is reluctant about the creation of such. From the herdsmen quarters, they believed the initiative is meant to launch an attack on them in the region. The federal government may also perceive the fear that the existence of Amotekun, would likely lay a precedent for other zones to engage in such initiative, and directly or indirectly threating the unity of the federation. In spite of these mixed feelings, this paper intend to beam a search light on the Amotekun, its modalities and theoretical insights with a view to providing information on the prospects and challenges of the regional security network.

\section{Methodology}

This paper draws largely from secondary sources of data which include books, journals articles (print and online), government publications, conference proceedings on the subjects under discourse. The justification for this method of data gathering is basically to harness detailed and comprehensive information from extant literature for robust and insightful discussion about the formation of Non-State Security Agencies. In addition, content analysis was utilised for the gathered information from secondary sources by placing notable emphasis on the conceptual perspectives of writers 
on regionalization of Non-State Security Agencies in Southwest Nigeria, theoretical explanations, methods mostly adopted and the concrete examples which are then used as the basis of arguments for the prospects and challenges of "Amotekun".

\section{Modalities}

Though it is a regional affair, each state has its units. The local government organ will coordinate the activities in its jurisdiction. Each local government will relate to the state command. The six-state commands will relate to regional command in that order. The regional command will operate from the control center in Ibadan, Oyo state and the operational base in Gbogan, Osun state, and work closely with the Developmental Agenda for Western Nigeria (DAWN) Commission, which provide administrative supervision for the initiative. Commissioner of police in each state will oversee the activities in each of the states. There would be provision for a security trust fund that will foot the bill of this agency, which the Commissioner of police will oversee. Each state is also expected to recruit the number of personnel they capable of maintaining.

More so, in an interview with the Nation Newspaper January 13, 2020, Prof. Itse Sagay (SAN) the Chairman, Presidential Advisory Committee against Corruption (PACAC) commend the initiative and the Governors of the region for standing to perform the constitutional responsibility as the Chief Security Officers of the various states, and not only that but also using part of the security votes to fund the initiative. Also, the Chairman of the Nigeria Bar Association (NBA) Ado-Ekiti Branch, Mr. Samuel Falade, argued that the Southwest Governors had not erred by setting up the outfit but only exercised the right under the law to secure lives and properties. And Chapter 2, Section 14 (2b) mandates the President and Governors to provide security across the country and the respective states. He stated further that though Section 214 and 215 of the 1999 Constitution of the Federal Republic of Nigeria explicitly mandated the police as the agency responsible for the protection of lives and properties. This often causes chaos among police and other paramilitary agencies especially the NSCDC. Even with this provision, Governors are not deterring from taking measures to reinforce the protection of lives and properties for the citizens. Another argument by Falade was that Section 20 of Administration of Criminal Justice system allows the private citizen to arrest any criminal and hand over to the police for proper investigation and prosecution, which under the context, operation Amotekun can arrest suspects, and hand them over to the police for next action.

The concepts of police and policing are not always mean the same thing, though it's been used interchangeably in everyday language. Policing is not the sole responsibility of the police, but the primary function of the police 
is policing (Bello,Magaji, \& Jamilu,2016). Other security agencies are engaging in policing, but are not the police. Every other security agencies both the state actors and non-state actors engaged in the duty of policing by ensuring compliance with existing laws and maintain precepts of social order by the citizens. The necessity of policing by all actors, both the state and nonstate actors becomes even more evident in Nigeria societies characterized by divers insecurities vices range from book-haram insurgency, kidnapping, armed robbery, herdsmen/ farmer clash, ritual killing, etc. Ikuteyijo (2008) also attests to the fact police in the different parts of Nigeria have been found wanting in the responsibility of securing lives and properties, especially in regard to combating criminality. Local vigilante groups have often come to the rescue of members of the public and this has also influenced the public perception of the police as ineffective in crime control. Governor Akeredolu of Ondo State and the Chairman of Southwest Governor's forum attest to the fact that security is more of an indigenous phenomenon, and that criminality is alien to Yoruba people; hence the need for non-state regional securities outfit that will support the statutory security agencies in the region in combating criminality.

\section{Theoretical Analysis}

According to Kelly (2007), new regionalism, faces an uphill battle. Federal forces in systemic prejudices in theory tend to challenge exhibition of regionalism. This was evident in the tussle between the federal government of Nigeria and the six (6) Governors of the Southwest Nigeria. The coming decade will be crucial to the literature on Amotekun. If regions in the world do not establish dynamics that are meaningfully independent from the formation of national forces, the new regionalism will subside what the national government has not been able to capture. Regionalists make five arguments for the regional level of analysis (Buzan and Waever 2003).

First, most states worry more about the neighbors than about distant states (Buzan and Waever 2003, Miller 2005). As Lemke (2002) has observed, most states confront a punishing "loss of strength gradient" over distance. Power projection is a luxury of great powers. Systemic theory misses the limitations on threat extension facing the large majority of states, especially the issues of multi-nationals kidnapping in Lagos and Ogun States. Although this theory may de-emphasize great power behavior, it simply recognizes dozens of states and billions of people. Highly limited threat potential means the security dilemma is uneven (Buzan 1991). States are not free 'billiard balls' but geographically fixed. Most can only "bounce" or "knock" into a few neighbors, so local dynamics will be much more intense for most states, thus the local security group with current regional intensity in Yorubaland. 
Second, when great powers do intervene in regions, much evidence suggests that local partners exploit external patrons to pursue local opponents (Acharya, 1992a, 1992b; Hemmer and Katzenstein 2002; Lemke 2002). Overlay is not a one-way process, as clients can blackmail, flip-flop, hedge, or otherwise strategically manipulate patrons. African and Arab countries in the Cold War routinely jousted and toyed with supposedly dominant patrons. Kim II Sung maneuvered China and the Soviet Union into competitive support for his expansionism. In the same way, the Southwestern Governors have fashioned Amotekun for complementing the security architecture of the country. Systemic theories see a simplistic one-way transmission of preferences from great powers to the rest miss the gamesmanship and other autonomy-generating techniques small states deploy. Regions have more autonomy than perceived.

Third, regionalism reflects the increasingly normative awkwardness of systemic overlay, that is, imperialism. Even though great powers may have excessive power resources, there is a growing norm that small states and regions deserve space (Falk and Mendlovitz 1973; Buzan and Waever 2003:68; Pugh and Sidhu, 2003). Fourth, Regionalists will accept that subsystems are formally open and that overlay is a constant threat. But the costs of penetration have risen substantially in a populous and politically mobilized like Nigeria. De-colonization and the collapse of bipolarity have set the regions free (Buzan and Waever 2003:19); de facto regional autonomy in security affas is the new norm (Lake and Morgan 1997a:6-7).

Moreover, Nigeria needs regional allies to cloak and translate its power. If a regional level of analysis was unwarranted in the imperial centuries because a restive periphery of social vices makes it so today. Fifth, and finally, regionalists reject too much insistence on parsimony as a doctrine blinder that leads to deep, indefensible mismatches between theory and reality (Hentz 2003:7-8). Shambaugh captures regionalism's general concern that systemic is too abstract and distant to capture regional dynamics (Hentz and Boas 2003). At the cost of parsimony, regionalist models are intended to enrich theory and fit regional behaviors better. The region is a good middle level, between the state and the overly abstract system (Hettne 2000:44). It captures the diversity of experience and, done rigorously, may generate new theoretical insights.

\section{Prospects of the Regional Framework of Amotekun}

The operation of the outfit would reduce the problem of inadequate manpower in the Nigeria Police Force. They would complement the Nigeria Police Force in undertaking more robust routine patrols in every nooks and cranny of the region. The initiative would serve as intelligent for conventional security. They would serve as the CCTV in most of the rural areas by gathering information about the crimes and suspicious activities for interpretation and 
proper action. The initiative would also serve as a process of building institutions in the region, and in the country at large. More-so, the outfit also reflects the process of building regional integration, and true federalism which had been eluded the nation for decades.

The level of security accountability to the populace would increase at the grassroots because of the involvement in the security. Community policing entails a synergy of efforts between the police and the local vigilante groups as well as other members of society (Ikuteyijo 2008). It would become easier for traditional rulers to be more useful in tackling the security of the domain, because of the intimacy and ownership that exist between the agency and the traditional ruler. The initiative would result in building the confidence of the people in the region about the trust of the government in securing the lives and properties. It would likely reduce the intention for criminality because there is the saying among the people at the instant of the launching of the initiative that "the fear of Amotekun is the beginning of wisdom for criminals".

If managed, it may serve as a good template to imbibe by other regions of the federation in combating insecurities. It may increase the morale of statutory securities agencies in service delivery, because it may serve as a check on them. Lastly, it would also serve as employment opportunities for the teeming youths in the region.

\section{Possible Challenges of the New Regional Configuration}

The fact that the southwest as a region has been at the forefront of the creation of state police in Nigeria, created a fear, especially from northern extraction that the Amotekun initiative is like a back door for the region to achieve that agitation. Even if the initiative commences, there would likely be keen attention and unnecessary attention on the activities of the Amotekun, especially from the Northern extraction. The initiative is prone to conflict with other statutory securities agencies, particularly the Nigeria Police Force, similar to some of the conflict that does occur between the NPF and NSCDC. The nature of the assignments of the outfit in combating criminality such as kidnapping, armed robbery, ritual killing, herdsmen/ farmer clash, may lead them to go beyond the boundary of just provide intelligent for police. Sometimes, they may need to act beyond just provide intelligent about criminality, but attack, and arrest criminals, even without proper notification of the Nigeria Police Force.

Also, the issue of the independence of the outfit would constitute conflict between the Amotekun and other securities agencies. The perspective that, the outfit should work independently within the states and relate regionally may cause conflict among the federal government, state government, and other security agencies. Another challenge that may confront the initiative is for the use of the structure to settle personal discord. This 
situation often occurred with the members of some non- state organization like OPC, who use the membership of the group to intimidate the people around them. The deployment for political purposes may also constitute a challenge that would face the initiative.

For the outfit to be effective and efficient in combat criminality there is need for them to be armed, even not just ordinary arm but sophisticated that can compete with the ones used by the criminal. Some people believed that the Amotekun should not carry arms because it would likely constitute a great challenge. If the initiatives achieve the objective of building confidence in the citizenry, this may lead to loss of trust in the Nigeria Police Force, and if not well managed, it may allow for conspiracy and anarchy among the security agencies.

\section{Concluding Remarks}

In conclusion, the Amotekun initiative is a regional effort in response to the challenges of insecurities that have pervaded the nation and particularly the southwest region. There is nothing too big in securing the lives and properties of the citizen, which is the primary function of any government. Every tier of government must ensure and encourage any decision that appropriates the security of the citizens. More-so, there is a need for proper synergy among the tiers of government and agencies of government in the security sector to achieve the ultimate goal of securing lives and properties populace. Amotekun is not illegal, but it needs to be legalized. There is a need for a legal framework from each state of the region for its establishment, operations and finance is inevitable. The operation guidelines should be more transparent to the populace. There should be strong cooperation between the initiative and the Nigeria Police Force to achieve the objective of the Western Nigeria Security Network.

\section{References:}

1. Acharya, A. (1992a). "Regionalism and Regime Security in the Third World: Comparing the Origins of the ASEAN and the GCC" in J. Brian (ed.) Insecurity Dilemma: National Security of Third World States. Boulder: Lynne Rienner Publishers.

2. Acharya, A. (1992b). Regional Military-Security Cooperation in the Third World: A Conceptual Analysis of the Relevance and Limitations of ASEAN. Journal of Peace Research, 29: 7-21 Bello, I, Magaji, S, \& Jamilu, I.M (2016) A paper presented in International Conference of Social Science and Law-Africa ((ICSS-Africa). Nigerian Turkish Nile University (NTNU), 11th$12^{\text {th }}$ May 2016. 
4. Buzan, B. (1991). People, States, and Fear: An Agenda for International Security Studies in the Post-Cold War Era. 2nd edition. Boulder: Lynn Rienner Publishers

5. Buzan, B. \& Waever, O. (2003). Regions and Powers. New York: Cambridge

6. Falk, R. \& Mendlovitz, S. (1973). "General Introduction" in R. Falk \& S. Mendlovitz (eds.) Regional Politics and World Order. San Francisco: W.H. Freeman

7. Hemmer, C. \& Katzenstein, P. (2002) Why Is There No NATO in Asia: Collective Identity, Regionalism, and the Origins of Multilateralism. International Organization 56:575- 607

8. Hentz, J. (2003). "Introduction: New Regionalism and the Theory of Security Studies" in J. Hentz, and M. Boas (eds.). New and Critical Security and Regionalism. Burlington, VT: Ashgate.

9. Hentz, J. \& Boas, M. (eds.). (2003). New and Critical Security and Regionalism. Burlington, VT: Ashgate.

10. Hettne, B. (2000). "Development, Security, and World Order: A Regionalist Approach" in S. Page (ed.). Regions and Development: Politics, Security, and Economics. London: Cass

11. Ikuteyibo, L.O (2008). The challenges of Community Policing in Nigeria. International Journal of Police Science \& Management. 11(3), 285-293.

12. Iloh E. C. \& Nwokedi M. E. (2019). "Non State Actors and Internal Security Management in Nigeria: The Case of Vigilante Groups" in O. Oshita, I. Alumona, F. Onuoha (eds.) Internal Security Management in Nigeria. Palgrave Macmillan, Singapore

13. Lake, D. \& Morgan, P. (1997). "The New Regionalism in Security Affairs" in D. Lake \& P. Morgan (eds.) Regional Orders: Building Security in a New World. University Park: Pennsylvania State University

14. Lemke, D. (2002). Regions of War and Peace. New York: Cambridge University Press

15. Miller, B. (2005) When and How Regions Become Peaceful: Potential Theoretical Pathways to Peace. International Studies Review, 7:229267.

16. Pugh, M. \& Sidhu, W. (eds.) (2003). The United Nations and Regional Security: Europe and Beyond. Boulder: Lynne Rienner Publishers

17. The Nation Newspaper, Monday, January 13, 2020. 